$\begin{gathered}\text { Dicle Üniversitesi Veteriner Fakültesi Dergisi } \\ \text { https://dergipark.org.tr/tr/pub/duvetfd } \\ \text { Araştırma Makalesi/Research Article } \\ \text { Dicle Üniv Vet Fak Derg 2021;14(2):136-141 } \\ \text { DOI: 10.47027/duvetfd.1014976 }\end{gathered} \quad$ e-ISSN:1308-0679
ISSN:1307-9972

\title{
Et ve Et Ürünleri Harcında Kullanılan Bazı Bitkisel Ürünlerin Histolojik Yapıları
}

\author{
Fadime TONBAK ${ }^{1, a, \bigotimes}$, Mehmet Hanifi YALÇIN ${ }^{2, b}$, Pelin DEMiR ${ }^{3, c}$ \\ ${ }^{1}$ Atatürk Üniversitesi, Veteriner Fakültesi, Gıda Hijyeni ve Teknolojisi Anabilim Dalı, Erzurum, Türkiye \\ ${ }^{2}$ Fırat Üniversitesi, Veteriner Fakültesi, Histoloji ve Embriyoloji Anabilim Dalı, Elazığ, Türkiye \\ ${ }^{3}$ Fırat Üniversitesi, Veteriner Fakültesi, Gıda Hijyeni ve Teknolojisi Anabilim Dalı, Elazığ, Türkiye \\ aORCID: 0000-0001-7308-512X; b ORCID: 0000- 0002-8131-7864; 'ORCID: 0000- 0002- 0824-1672
}

\begin{tabular}{ccc}
\hline Geliş Tarihi/Received & Kabul Tarihi/Accepted & Yayın Tarihi/Published \\
10.08 .2021 & 09.11 .2021 & 31.12 .2021 \\
\hline
\end{tabular}

\section{Öz}

Bu çalışmada et ve et ürünleri harcına karıştırılmış çeşitli un, bitki ve baharatların hayvansal dokulardan ayrıştırılmasının kolaylaştırılması amaçlanmıştır. Çalışmada kullanılan kırmızı et, un, bitki ve baharatlar şehir merkezindeki satış noktalarından temin edilmiştir. Bitkisel kökenli katkılar, et ürünlerine katıldı̆̆ büyüklükte kıyılarak \%10 oranında sığır eti kıymasına karıştırımış ve hematoksilen-eozin boyama yöntemi ile histolojik incelemeleri yapılmıştır. Bitkisel dokularda kendine özgü şekilleriyle hücre duvarları ve farklı plastit yapıları görülürken, iskelet kasının enine kesitlerinde sarkolemin altında birden fazla çekirdek, boyuna kesitlerinde ise düzenli bantlaşma bulguları dikkat çekmektedir. Sonuç olarak, et ve et ürünlerinde kullanılan bazı baharatların doğru tespitinin yapılabilirliği test edilmiştir. Mikroskop alanında her zamankinden daha fazla baharat tespit edilmesi, bozulan koku, tat ve rengi dengelemek adına bazı hilelerin olabileceğini akla getirmelidir.

Anahtar Kelimeler: Baharat, bitkisel katkılar, et ve et ürünleri, gıda tağşişi, histolojik analiz

Investigation of Histological Structures of Some Herbal Additives Used in Meat and Meat Products Mortar

\section{Abstract}

In this study, it was aimed to facilitate the separation of various flour, herb and spices mixed into meat and meat products mortar from animal tissues. Red meat, flour, herbs and spices used in the study were obtained from sales points in the city center. Additives of vegetable origin were chopped to the size of meat products and mixed with $10 \%$ beef mince, and histological examinations were made by hematoxylin-eosin staining method. While cell walls and different plastid structures with their unique shapes are seen in plant tissues, more than one nucleus under the sarcolemma in the transverse sections of the skeletal muscle and regular banding findings in the longitudinal sections draw attention. As a result, the feasibility of accurate detection of some spices used in meat and meat products was tested. The detection of more spices than ever before in the microscope field should suggest that there may be some tricks to balancing the spoiled odour, taste and color.

Key Words: Spices, herbal additives, meat and meat products, food adulteration, histological analysis

\section{GiRiş}

Beslenme, insan hayatının sağııkı bir şekilde sürdürülmesinde büyük önem taşımaktadır. Artan dünya nüfusu, besin kaynaklarının kısıtlılığı gibi etmenler, dengeli ve yeterli beslenmenin önemini gün geçtikçe daha da arttırmaktadır. Bunun yanında, insan beslenmesinde gerek bitkisel gerekse hayvansal kaynaklı besin maddelerinin de aynı oranda artış göstermesi gerekmektedir. Vücut faaliyetlerinin yerine getirebilmesi için her iki besin grubunun da dengeli tüketilmesi önemlidir (1).

Dünya çapında endüstrilerin gelişmesiyle, günümüzde et ve et ürünlerini daha ucuza mal edebilmek için, firmalar tarafından yapılabilecek tağşişli et ürünleriyle ilgili endişeler tüketicilerde giderek artmaktadır (2). Bu işlem sadece tüketiciyi yanıltmakla kalmaz aynı zamanda sağlıklı ürün karşısında haksız rekabet ortamının oluşturulmasına ve gıda güvenliği kavramının çiğnenmesine neden olmaktadır. Pahalı ve kaliteli etlere kâr elde etmek için aynı ya da farklı türden olması gözetilmeksizin, ucuz ve düşük kaliteli etlerin karıştırılması ile ciddi bir halk sağlığı sorunu oluştuğu bildirilmektedir (3). Et ve et ürünlerine farklı hayvan türlerinin karıştırılması hem helal gıda endişesini getirmekte hem de mikrobiyal, toksik, alerjik ve zoonoz hastalıkların riski ile tüketicileri endişelendirmektedir.

Kırmızı et, en önemli hayvansal kaynaklardandır. Beslenme piramidi gözden geçirildiğinde et, yumurta, kanatlı eti ve balıketi ile birlikte hayvansal protein grubu içerisindedir. Et proteini, biyolojik öneme sahip proteinlerin ana kaynağı olmasının yanında, içerdiği vitamin, mineral, su ve diğer besin elementlerinden dolayı insan beslenmesi ve insan sağlığı açısından da büyük önem taşımaktadır $(4,5)$. 
Köfte, sucuk, salam, sosis, pastırma, kavurma, döner, jambon, pate, mergez vs. çeşitli et ürünleri severek tüketilmektedir. Köfte, Akçaabat köfte, İnegöl köfte, İzmir köfte, Tire köfte, Tekirdağ köfte, kadınbudu köfte, kasap köfte, içli köfte, kuru köfte (anne köftesi), dalyan köfte, Hasanpaşa köfte, sucuk köfte, ıslama köfte, çiğ köfte, dondurulmuş köfte gibi ürünlerle çeşitliliği fazla olan et ürünlerindendir. Türk Gıda Kodeksi (TGK) (6)' ne göre köfte, 'kıyılmış büyükbaş ve küçükbaş hayvan karkas etlerinin veya kanatlı hayvan karkas etlerinin bu Tebliğe uygun olacak şekilde biri veya birkaçının karışımına, aynı ve/veya farklı tür hayvanların yağları, lezzet vericiler ile diğer gıda bileşenlerinden biri veya birkaçı ilave edilerek çeşitli şekillerde hazırlanan pişirilmeye hazır kırmızı veya kanatlı et karışımı veya pişirilmiş et ürünüdür" şeklinde tanımlanır.

Oksidasyon, et kalitesinin ve et ürünlerinin raf ömrüne etkisinin başlıca nedeni olarak kabul edilmekte ve etin besin değerinde, duyusal ve fizikokimyasal özelliklerinde olumsuz değişikliklere yol açmaktadır. Baharatlar ve bitki materyalleri, sağlığa faydalı potansiyel etkileri olan biyoaktif bileşikler açısından zengin olduğundan, doğal antioksidanlar oksidasyona alternatif çözüm olabileceği ve tüketicilerin doğal ürünleri kullanmaya olan ilgisinin artmasıyla paralel olarak, sentetik antioksidanların ve koruyucuların doğal olanlarla değiştirilmesi beklentisi oluşmuştur $(7,8)$.

Et ve et ürünlerinde yapılan üretim hilelerinin ortaya çıkarılması ve miktar tayinleri konusunda Gıda Kontrol Laboratuvarların ve araştırmacıların kullandığı pek çok metot bulunmaktadır. Günümüzde et ürünlerini incelemek için anatomik, histolojik, mikroskobik, organoleptik, kimyasal, elektroforetik, kromatografik veya immünolojik yöntemlere dayanan çeşitli analitik metotlar kullanılmaktadır (9). Bu yöntemlerin çoğu hayvan tür tanımlamasında uygun hassaslıkta olsa bile, aynı türün farklı dokularının tespitinde kullanılması pek mümkün olmazken $(10,11)$, yabancı doku 'var/yok' şeklinde raporlandığından, tespit edilmesi durumunda karışımın ne oranda olduğunu ölçmek pek mümkün olamamaktadır. Farklı hayvan türlerinin ayırt edilmesinde $\operatorname{ELISA}(12,13)$ ve $\operatorname{PCR}(2,14)$ metotları kullanılmaktadır. Spektroskopik tabanlı kemometrik analizler Fourier transformed-infrared spectroscopy (FT-IR) (15), hızlı buharlaştırıcı iyonizasyon kütle spektrometrisi Rapid evaporative ionisation mass spectrometry (REIMS) (16) yöntemleri de son zamanlarda optimize edilerek kullanılmıştır. Son yıllarda, mikroskobik bir yöntem olan Histolojik Muayene Analizi $(17,18)$ daha çok tercih edilen yöntemler arasındadır. Bazı araştırıcılar, tağşiş amacı ile kullanılan doku ve organların tespitinde histolojik muayenenin, tüketicilerin daha kaliteli ürünler tüketmesine yardımcı olan faydalı bir yöntem olduğunu vurgulamıştır $(10,18)$.

Ülkemizde, 5996 Sayılı Veteriner Hizmetleri, Bitki SağIığı, Gıda ve Yem Kanunu' nun 31 inci maddesinin 6' ncı fıkrası uyarınca Tarım ve Orman Bakanlığı bünyesinde sınırlı sayıda Gıda Kontrol Laboratuvar Müdürlüklerince yapılan Histolojik Muayene Analizi sonuçları kamuoyu bilgisine sunulmaktadır. Yapılan denetimler ve analizler sonucunda taklit ve tağşiş yaptığı belirlenen işletmeler ve ürünler arasında ilk sırayı genelde, süt ve süt ürünleriyle et ve et ürünleri ve alkollü içecekler paylaşmaktadır (19)
Bu çalışma, et ve et ürünleri harcına karıştırılması muhtemel un, bitki ve baharatların, hematoksilen-eozin metodu ile boyanan kesitlerinde histolojik görüntülerinin tespit edilmesi ve hayvansal dokulardan ayırt edilmesini kolaylaştırmak amacıyla yürütülmüştür.

\section{MATERYAL VE METOT}

Çalışma, kontrol grubu (sığır eti kıyması), un grubu, sebze grubu ve baharatlar grubu olmak üzere 4 gruba ayrılmıştır (Tablo 1). Çalışma materyali olarak kontrol grubunu oluşturan sığır eti kıyması kasaptan (Elazığ, Türkiye) alınmış, bonfile olarak tanımlanan hayvanın sırt kısmında bulunan yağsız kastan elde edilmiştir. Un grubu, marketlerde satılan galeta unu, buğday unu ve mısır unundan (Bağdat, Türkiye) oluşmaktadır. Sebze grubunda manavdan (Elazığ, Türkiye) temin edilen maydanoz, sarımsak ve soğan bulunmaktadır. Kekik, nane, karabiber, kırmızı toz biber ve kimyon ise aktarlardan (Elazığ, Türkiye) temin edilen baharatlar grubunu oluşturmaktadır. Et ürünlerinde bulunması muhtemel bu katkılar sığır eti kıymasına \%10 oranında karıştırıldı. Karışım $4^{\circ} \mathrm{C}^{\prime}$ de 6 saat tutuldu ve tüm gruplara TS 13511/2012' deki metot uygulandı (20).

Tablo 1. Çalışmada kullanılan materyaller ve grup düzenekleri

\begin{tabular}{llll}
\hline $\begin{array}{l}\text { Kontrol } \\
\text { (GK) }\end{array}$ & $\begin{array}{l}\text { Un Grubu } \\
\text { (G1) }\end{array}$ & $\begin{array}{l}\text { Baharat Grubu } \\
\text { (G2) }\end{array}$ & $\begin{array}{l}\text { Sebze Grubu } \\
\text { (G3) }\end{array}$ \\
\hline $\begin{array}{l}\text { Sığır kırmızı } \\
\text { eti }\end{array}$ & Buğday unu & Kimyon & Soğan \\
& Mısır unu & Kekik & Sarımsak \\
& Nane & \\
& Galeta unu & $\begin{array}{l}\text { Karabiber } \\
\text { Kırmızı toz biber }\end{array}$ & Maydanoz \\
\hline
\end{tabular}

$4^{\circ} \mathrm{C}$ 'de dinlenme aşaması tamamlanan karışımların her birinin 5 farklı bölgesinden yaklaşık 1-1.5 cm boyutunda 2' şer adet örnek alındı ve tespit amacıyla plastik doku takip kasetlerine konuldu. Alınan numuneler, \%10' luk formaldehit (Merck 103999, Darmstadt, Germany) çözeltisinde 24 saat süre ile bekletildi. Numuneler tespit edildikten sonra, 12-18 saat akarsu altında tutularak numunelerden formaldehit uzaklaştırıldı. Tespit ve akarsu işlemlerinden sonra, numuneler rutin histolojik takip serilerinden geçirildi (21). Daha sonra alınan örnekler parafin bloklara gömüldü ve bu parafin bloklardan mikrotom (Leica, RM2125, Wetzlar, Germany) ile 5-6 mikron kalınlığında kesitler alındı. Alınan kesitler hematoksilen (Merck 105174, Darmstadt, Germany)-eozin (Merck 109844, Darmstadt, Germany) metodu ile boyandı (22). Boyanan preparatlar ışık mikroskobu (Leica, DM500, Germany) ile incelendi ve gerekli bölgelerin fotoğrafları kamera (Leica, DFC295, Germany) ile dijital ortamda kaydedildi.

\section{BULGULAR}

Sığır kıymasına karıştırılmış katkıların histolojik görünümleri ışık mikroskobunda incelendi ve bu yapılar Şekil 1 ve Şekil 2' de gösterildi.

Sığır iskelet kası, isteğe bağlı hareketi sağlayan çizgili kastan oluşmaktadır. Şekil 1.A'da bu kas hücreleri bir hücre zarı ile çevrili durumda sınırlanmış ve ikili, üçlü görülebilen 
çok sayıda mavi-mor boyalı çekirdek içermektedir (sarı ok). Birden fazla olan bu çekirdekler, hücre zarının hemen altında bulunmasıyla dikkat çekmektedir. Çizgili (iskelet kası) kas liflerinin boyuna kesitlerinde kasılma mekanizmalarında görev alan, açık ( I bantları) ve koyu (A bantları) renkli miyofilamentler bulunmaktadır (siyah ok).

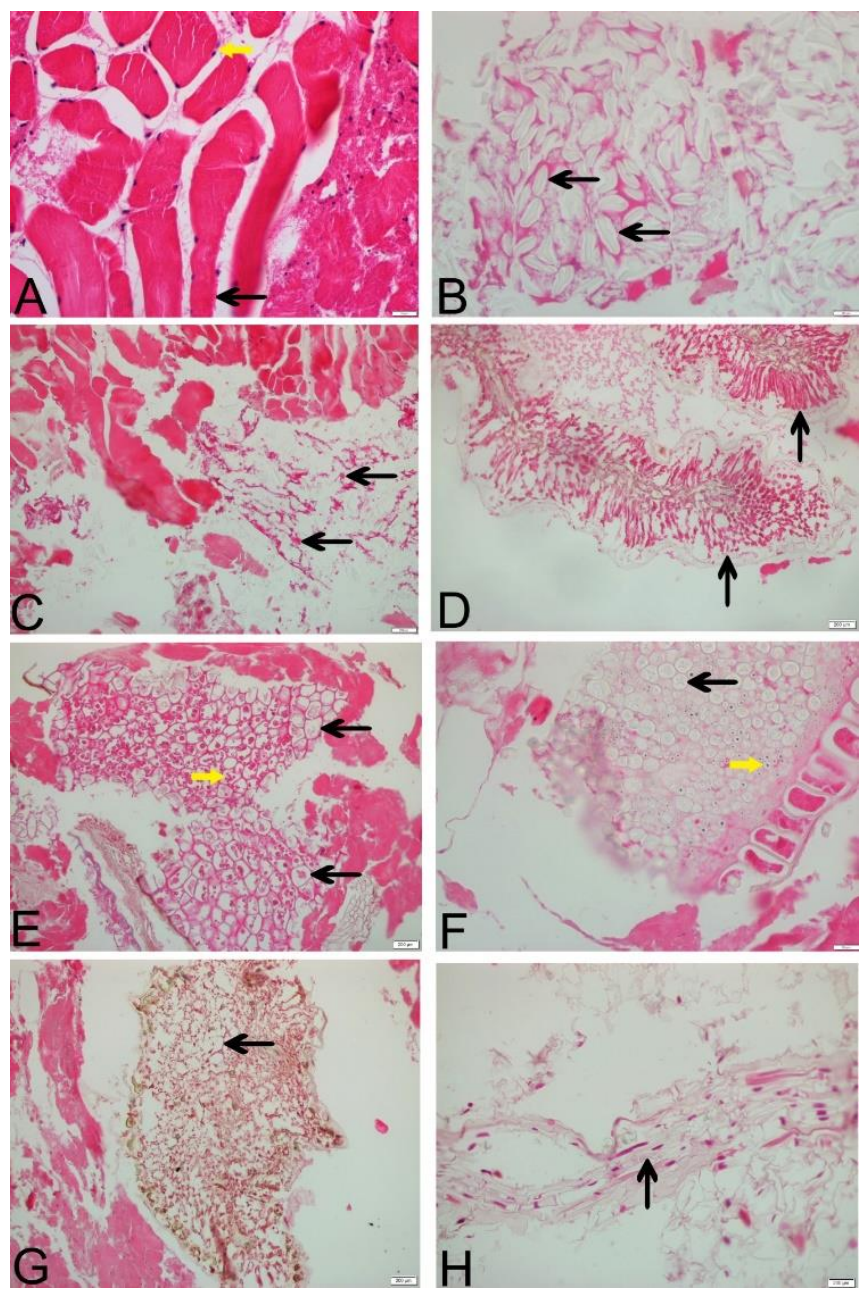

Şekil 1. Kas hücreleri, çeşitli un, bitki ve baharatlara ait yapılar (1.A: Kas hücreleri; 1.B: Buğday unu; 1.C: Galeta unu; 1.D: Kekik; 1.E: Kimyon; 1.F: Mısır unu; 1.G: Nane; 1.H: Sarımsak).

Şekil 1.B'de buğday unu içerisindeki karakteristik yapılar buğday tanesi gibi görülmektedir (siyah ok). Şekil 1.C'de ise buğday unundan yapılmış galeta unu, tiroid foliküllerinin içinde bulunan, kolloid benzeri yapılara benzer düzgün olmayan yapılar burada da mevcuttur (siyah ok). Isıl işlemin etkisiyle unda görülen yapıların bütünlüğünün bozulmadığı burada görülmektedir. Şekil 1.F'deki mısır unu kesitlerinde ise görülen hücre duvarı, komşu hücreleri birbirlerinden net olarak ayırmıştır. İri hücreler içerisinde yıldızımsı yapılar görülürken (siyah ok) küçük hücrelerin içerisinde ise çekirdeğe benzer yapılar mevcuttur (sarı ok).

Şekil 1.D’de kendine özgü sınırlandırılmış hücre yapılarıyla kurutulmuş kekik yaprağının mikroskobik görüntüsü mevcuttur (siyah ok). Toz haline getirilmiş kimyonun histolojik kesitleri incelendiğinde (Şekil 1.E), kıkırdağın kondrositlerine benzemekle birlikte hücreler birbirlerinden belirgin bir hücre duvarı ile ayrılmıştır (siyah ok). Kimyon kesitleri içerisindeki damlacık tarzı bir ve birden fazla irili ufaklı yapılar dikkat çekmektedir (sarı ok).

Şekil 1.G'de hematoksilen-eozin ile boyanmış nane yaprağı görüntüsü bulunmaktadır. Histolojik yapılarda lümen etrafında çekirdek dizilimi hayvansal doku kesitlerinde seröz ve müköz bezleri andırsa da kendine has hücre duvarı yapısı dikkat çekmektedir (siyah ok). Benzer olarak Şekil 1.H'de sarımsak kesitleri görülmektedir. Buradaki görüntü, iskelet kasındaki boyuna kesitlerde görülen bant yapılarına benzerken, içi boş görüntüsüyle yağ hücrelerine de çok benzemektedir (siyah ok).

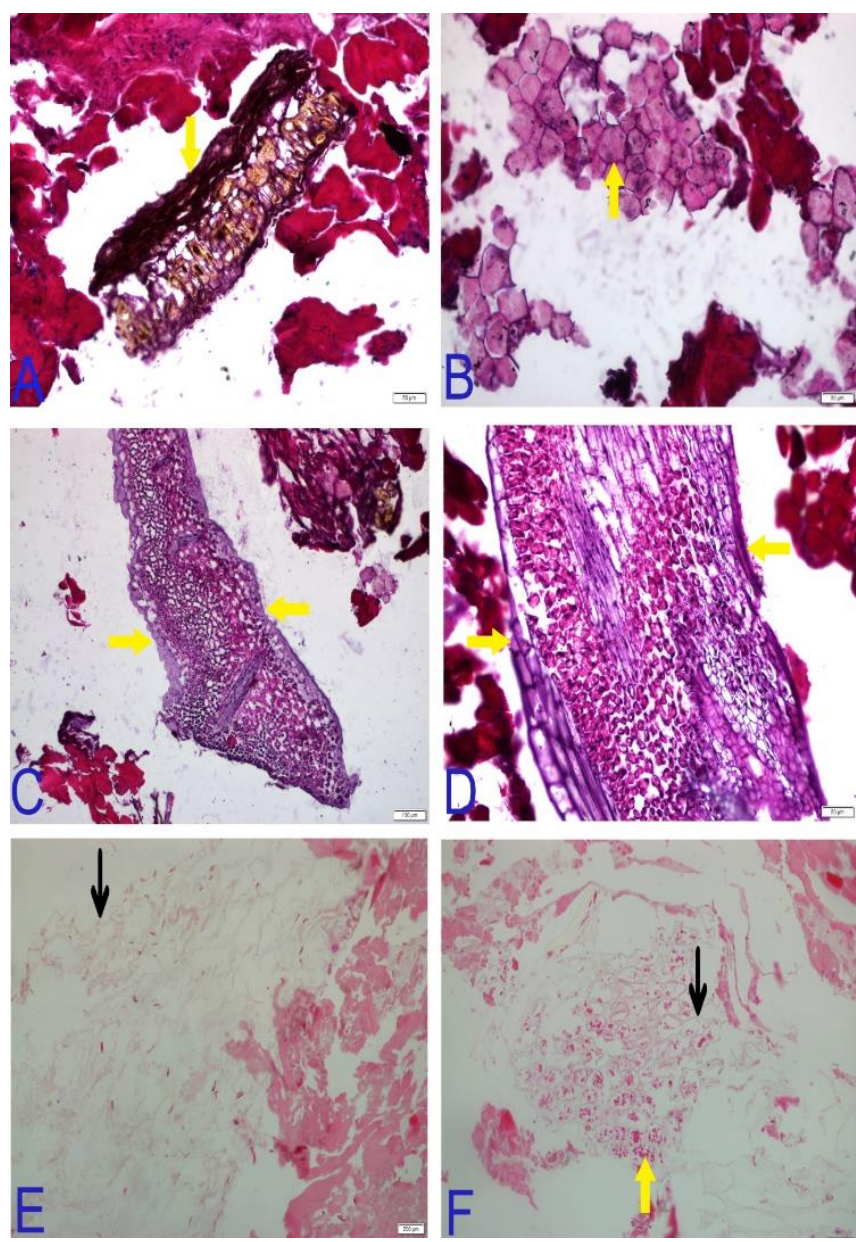

Şekil 2. Karabiber, maydanoz, kuru soğan ve kırmızı toz bibere ait yapılar (2.A ve 2.B: Karabiber; 2.C ve 2.D: Maydanoz; 2.E: Kuru Soğan; 2.F: Kırmızı Toz Biber).

Karabiber kesitleri Şekil 2.A ve Şekil 2.B'de görülmektedir. Şekil 2.A'da karabiberin derideki keratine benzer yapısı mevcut olsa da karabiberdeki hücrelerin belirgin bir hücre duvarı bulunmaktadır (sarı ok). Şekil 2.B' de ise kabuk kısmından farklı, tohumun iç kısmı olduğunu düşündüğümüz karabibere özgü karakteristik yapılar mevcuttur (sarı ok). Şekil 2.C ve Şekil 2.D'de ise taze maydanozun yeşil yapraklarının mikroskop görüntüsü bulunmaktadır (sarı ok). Şekil 2.E'de kuru soğanın hematoksilen-eozin ile boyanmış kesitleri mevcut iken (siyah ok), Şekil 2.F'de kırmızı toz biberin belirgin hücre duvarlarıyla (siyah ok) içerisinde görülen nokta şeklinde kırmızı yapıları (sarı ok) dikkat çekmektedir. Bu çalışmada kullanılan tüm karışımların benzerlik ve farklılıkları Tablo 2' de gösterilmiştir. 
Tablo 2. Çalışmada kullanılan karışımların benzerlik ve farklılıkları

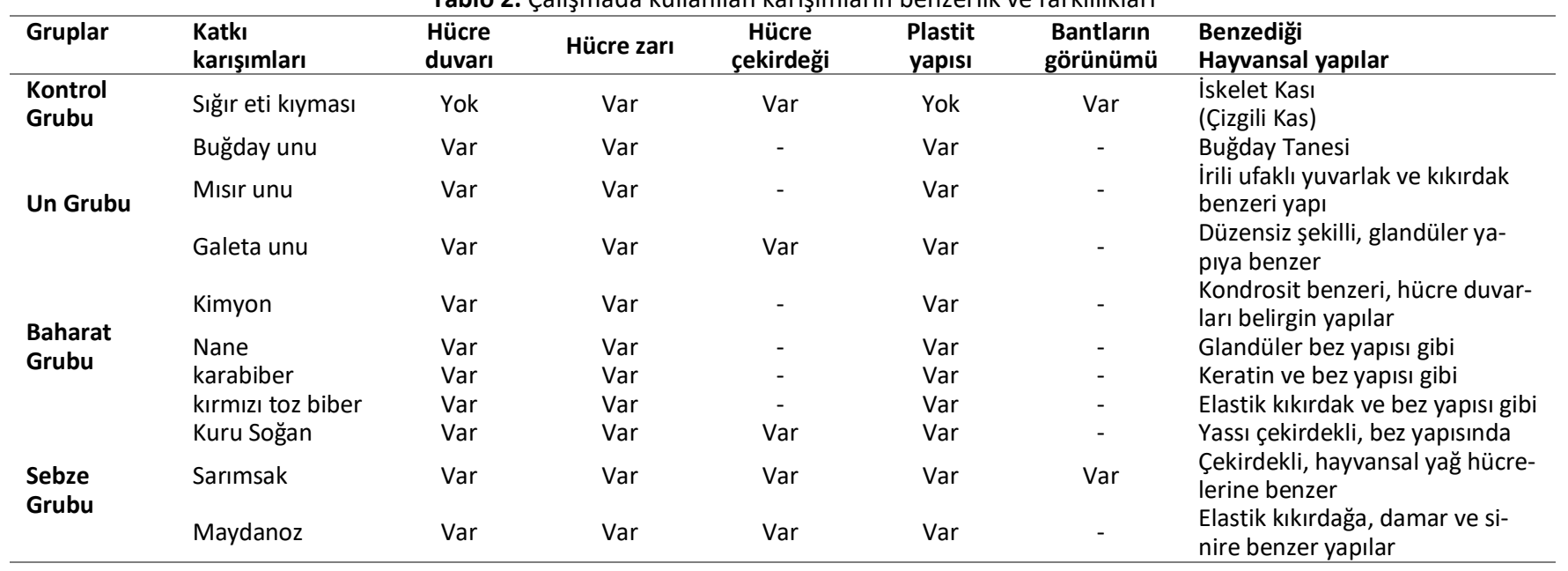

\section{TARTIŞMA VE SONUÇ}

Son zamanlarda, gelişen teknolojiyle birlikte mevzuata uygun olmayan et ve et ürünleri, halk sağlığı ve gıda güvenliği için ciddi bir sorun haline gelmiştir. Adil ticaret ve dini düşünce gibi birçok konu et hileleriyle doğrudan etkilenmektedir. Bu nedenle, günümüzde gıdanın kaynağını öğrenmek tüketicinin gıdayı tercih sebebi olmaktadır (9).

Bu çalışmada olması gereken sığır kas hücreleri bir hücre zarı ile çevrili görülmektedir. Bu hücre zarına Sarkolemma adı verilir. Sarkolemma altında ikili, üçlü görülebilen çok sayıda mavi-mor boyalı çekirdek dikkat çekmektedir. Birden fazla olan bu çekirdekler, hücre zarının hemen altında bulunmasıyla dikkat çekmektedir. Kas hücrelerinde sarkoplazma içerisinde protein yapısında miyofibrilleri oluşturan açık ve koyu renkli miyofilamentler bulunmaktadır. Boyuna kesitlerde $A$ bandı koyu renkte görülürken I bandı açık renkte görülmektedir.

Maydanoz, nane ve kekik gibi bitkilerin yeşil kısımları, taze ve kuru olarak et ürünlerinde kullanılmaktadır. Damak tadına uygun olarak, karabiber ve kimyon gibi bazı bitkilerin tohumları, sarımsak ve soğan gibi bazı bitkilerin ise yeşil yaprak, kök ve yumruları et ürünleri harcına karıştırılmaktadır. Genel olarak bitkilerin histolojik yapıları, hayvansal hücre yapılarından önemli derecede farklılıklar içermektedir. Bitki dokularında, hücreyi dış etkenlerden koruyan ve ona şekil veren selülozik bir hücre duvarı bulunmaktadır. Bu nedenle bitki hücreleri ışık mikroskobunda belirgin dikdörtgen, yuvarlak veya çokgen şekillere sahip olarak hayvansal hücrelerden kolayca ayırt edilirler.

Bazı işletmeler, raf ömrü tükenmiş hayvansal dokuların bozulmalarından dolayı ortaya çıkacak koku, tat ve rengi bastırmak amacıyla ürünlerde baharat miktarını arttırmıştır. Yapılan histolojik muayenelerde mikroskop sahasında bitki hücrelerinin normalden fazla görülmesi üründe bir hile yapılmış olabileceğini akla getirebilir $(10,11)$. Sunulan bu çaIışmada mikroskop sahalarında, deneme amaçlı katılan baharat sahaları görülmektedir. Normal şartlarda ürün harcına katılan baharatlardan kırmızıbiber ile yapılan bir çalışmada, $\% 2$ oranında ürüne katılması lipid oksidasyonunu önlemede çok etkili bulunmuştur. Bunun mikrobiyal büyümeyi ve lipid oksidasyonunu inhibe ederek kötü koku oluşumunun gecikmesine neden olduğu da bildirilmiştir (23). Bu çalışmada \%10 oranında deneme amaçlı olarak köfte harcına kırmızı toz biber ilavesi yapıldı ve mikroskop sahasında kolayca görüntüleri tespit edilebildi.

Baharatların mikroskobik yapıları incelendiğinde hayvan hücrelerinden farklı olarak bazı yapılar görülmektedir. Hücre duvarı dışında bitki hücrelerinde plastit (kloroplast, kromoplast ve lökoplast) adı verilen hücre organelleri bulunmaktadır. Bitkilerde kloroplastlar fotosentez yoluyla güneş ışığından enerji üretir ve bitkinin yeşil kısmını oluşturur. Bu rengi maydanoz, nane ve kekik gibi baharatlar kurutulduğunda bile muhafaza edebilmektedir. Bitki hücrelerinde, yeşil (sarı (ksantofil), turuncu (karoten), kırmızı (likopen) renkte) dışındaki renkleri veren kromoplast denen yapılar da vardır. Kromoplastların şekilleri her zaman muntazam olmaz. Soğan, sarımsak, mısır ve buğday gibi bitkilerin depo organlarının hücrelerinde bulunan nişasta, yağ ve protein içeren lökoplastlar ise renksiz olarak görülen plastitlerdir. Bitki hücresinde büyük yer kaplayan bir diğer organel de merkezi vakuoldür (24). Sunulan çalışmada, kırmızıbiber ve kimyon gibi bitkisel dokularda kromoplast oldukları tahmin edilen çok sayıda oluşum görülmektedir.

Nane yaprağında görülen yapılar hayvansal doku kesitlerinde seröz ve müköz bezlere benzemekte ama kendine has hücre duvarı yapısıyla kolaylıkla seröz ve müköz bezlerden ayrılabilir. Benzer olarak sarımsak kesitlerindeki görüntü, iskelet kasındaki boyuna kesitlerde görülen bant yapılarına ve bu yapıların etrafındaki oluşumlar ise yağ hücrelerine benzemektedir. Ancak, sarımsaktaki bant benzeri yapılar iskelet kasının aksine düzensiz olup, çekirdek sayısı ve lokalizasyonu da farklıdır.

Son zamanlarda, tüm dünyada olduğu gibi ülkemizde de ekonomik kaygı ve kolay yoldan kazanç elde etme isteği, bazı üreticileri gıda üretiminde hileye yöneltmektedir. Ülkemizde gıda tağşişi ve muhtemel halk sağlığı sorunlarını önlemek için TGK Et ve Et Ürünleri Tebliği yayımlanmıştır (6). Bu tebliğ, çiğ et, kıyma, hazırlanmış et karışımları ve et ürünlerinin tekniğine uygun olarak üretilmesi, ambalajlanması ve piyasaya arzına ilişkin hususları belirlemektedir. Tebliğin 5 . maddesine göre çiğ et, kıyma, hazırlanmış et karışımları ve et ürünlerinde, büyükbaş ve küçükbaş hayvan etleri birbirleriyle karıştırılabilirken, kanatlı hayvan türlerinden elde edilen etler de birbirleriyle karıştırılabilir. Ancak, belirtilen durumlar dışında farklı hayvan türlerine ait etler birbirleriyle 
karıştırılamaz. Tebliğ kapsamında yer alan çiğ kırmızı et, çiğ kanatlı eti, kıyma, hindi kıyması, hazırlanmış kırmızı et karışımları ve hazırlanmış kanatlı eti karışımları, Gıda Hijyeni Yönetmeliği (4) ve Hayvansal Gıdalar İçin Özel Hijyen Kuralları Yönetmeliğinde (25) yer alan kurallara uygun olarak elde edilmek zorundadır. Aynı zamanda böyle ürünleri üreten veya satan işyerlerinde farklı hayvan türlerine ait etler birbirinden ve diğer gıdalardan ayrı olarak üretilir ve ayrı olarak satışa sunulur hükmü bulunmaktadır (6).

Et ürünlerinin depolama süresini uzatmak, lezzeti artırmak ve renk vermek amacıyla nane, kekik, karabiber, kırmızıbiber, kimyon, sarımsak, soğan gibi bitkisel yapılar ürün harçlarına eklenmektedir. Bazı baharatların güçlü antioksidan ve antimikrobiyal özelliklerinden faydalanılmaktadır. Özellikle sucuk, salam ve sosis yapımında kimyon, karabiber, sarımsak, kırmızıbiber gibi baharatlar, tüketicinin taleplerine ve ülkemizin coğrafi yapısına göre değişen miktarlarda kullanılmaktadır. Güneydoğu Anadolu Bölgesinde çok acılı ürünler tercih edilirken, Batı Anadolu Bölgelerimizde ise daha az acılı ürünler tercih edilmektedir $(26,27)$. Mikroskop alanında kabul edilebilir seviyelerden fazla baharat gözlenmesi, raf ömrü tükenmiş hayvansal dokuların ürün harcında kullanılmış olabileceği düşüncesini de akla getirmektedir $(10,11)$.

Sonuç olarak, gelişmiş teknolojiler kullanılarak yapılan et ürünleri içerisinde, yasal düzenlemelere rağmen mevzuata uygun olmayan sonuçlar görülebilmektedir. Teknolojinin gelişmesiyle hile amaçlı veya tarihi geçmiş ürünlerin olumsuzluklarını örtmek için et ve et ürünlerine yabancı doku, organ ve aşırı miktarda bitkisel katkıların kullanılması sıkça karşılaşılan bir durum haline gelebilir. Et ürünlerinde kullanılabilecek baharatların histolojik yapıları ışık mikroskobunda belli oranlarda tespit edilebilmektedir. Gıda güvenliği ve halk sağlığı açısından kullanılabilecek her baharat ve bitki karışımları için daha fazla çalışmaya ihtiyaç duyulmaktadır.

\section{Çıkar Çatışması}

Yazarlar bu çalışmada herhangi bir çıkar çatışması olmadığını beyan ederler. Makale daha önce yayımlanmamıştır ve başka bir dergide yayınlanmak üzere değerlendirilmemektedir. Makale tüm yazarlar tarafından okunmuş ve onaylanmıştır.

\section{KAYNAKLAR}

1. Anonim, (2018). Tarım İşletmeleri Genel Müdürlüğü 2018 Yılı Hayvancilık Sektör Raporu.http://www.byclb.com/Files/ sektor_raporlari /Hayvancilik-Sektor Raporu.pdf.

2. Song $Q$, Chen $Y$, Zhao L, Ouyang H, Song J. (2019). Monitoring of sausage products sold in Sichuan Province, China: A first comprehensive report on meat species' authenticity determination. Sci Rep. 9(1): 19074-19082.

3. Li X, Guan Y. (2019). Specific identification of the adulterated components in beef or mutton meats using Multiplex PCR. J AOAC Int. 102(4): 1181-1185.

4. Budak A, Kayaardı S. (2006). Et ve et ürünlerinde yağ oranının düşürülmesi. Akademik Gıda 4(6): 6-10.

5. Özlü S, Ercoşkun H. (2021). Et ve Sağııkı Beslenme. Gıda ve Yem Bilimi-Teknolojisi Dergisi 25(1): 15-29.

6. Türk Gıda Kodeksi (TGK). (2019). Et ve Et Ürünleri Tebliği. No: 2018/52.
7. Çoban ÖE, Patır B. (2010). Antioksidan Etkili Bazı Bitki ve Baharatların Gıdalarda Kullanımı. Electronic Journal of Food Technol. 5: 7-19.

8. Horbańczuk OK, Kurek MA, Atanasov AG, et al. (2019). The effect of natural antioxidants on quality and shelf life of beef and beef products. Food Technol Biotechnol. 57: 439-447.

9. Kumar A, Kumar RR, Sharma BD, et al. (2015). Identification of species origin of meat and meat products on the DNA basis: $A$ review. Crit Rev Food Sci Nutr. 55: 1340-1391.

10. Karaca S. (2017). Deneysel Olarak Dil, Ön Mideler, Abomazum, Taşlık, Baş Eti, Kemik ile Soya, Kimyon ve Sarımsak illave Edilerek Hazırlanan Fermente Sucuklarda Histolojik Analizler. Yüksek Lisans Tezi. Selçuk Üniversitesi Sağlık Bilimleri Enstitüsü, Konya.

11. Karaca GP. (2017). Deneysel Olarak Trakea, Akciğer, Özefagus, Kalp, Dalak ve Lenf Yumrusu ile Yenibahar, Kırmızı Toz ve Kırmızı Pul Biber Illave Edilerek Hazırlanan Fermente Sucuklarda Histolojik Analizler. Yüksek Lisans Tezi. Selçuk Üniversitesi Sağlık Bilimleri Enstitüsü, Konya.

12. Türkyılmaz Ö, Irmak H. (2008). Et ve et ürünlerinde ELISA tekniği ile türlerin tespiti. Bornova Vet Kont Araşt Enst Derg. 30: 27-31.

13. İşleyici Ö, Sancak YC, Tuncay RM ve ark. (2017). Investigation of the Existence of Poultry and Equidae Meat Sold in the Form of Salami, Sausages and Sujuk Consumed in Van with ELISA Technique. Van Vet J. 28: 107-111.

14. Khairil Mokhtar NF, El Sheikha AF, Azmi NI, et al. (2020). Potential authentication of various meat-based products using simple and efficient DNA extraction method. J Sci Food Agric. 4: 16871693.

15. Hu Y, Zou L, Huang X, et al. (2017). Detection and quantification of offal content in ground beef meat using vibrational spectroscopic-based chemometric analysis. Sci Rep. 7: 15162-15171.

16. Black C, Chevallier OP, Cooper KM, et al. (2019). Rapid detection and specific identification of offals within minced beef samples utilising ambient mass spectrometry. Sci Rep. 9: 62956304.

17. Wijnker JJ, Tersteeg MH, Berends BR, et al. (2008). Quantitative histological analysis of bovine small intestines before and after processing into natural sausage casings. J Food Prot 71: 1199204.

18. Ince E, Özfiliz N. (2018). Detection of adulterations in fermented and heat-treated Turkish type sausages by histological examination. Ankara Üniv Vet Fak Derg. 65: 99-107.

19. T.C. Tarım ve Orman Bakanlığı ifşa listesi. Eylül/2020. https://www.tarimorman.gov. tr/04.04.2021.

20. Türk Standardları Enstitüsü (TSE). (2012). ETS 13511. Et ve Et Mamulleri-Laboratuvar Analiz Yöntemleri-Histolojik Muayene/Meat and meat products-Laboratory analysis methodsHistological examination. Et ve Et Ürünleri.

21. Demir R. (2001). Temel Histolojik Teknikler. (Içinde): Histolojik boyama teknikleri, 1. Baskı, s. 1-49. Palme Yayıncılık, Ankara, Türkiye.

22. Üstünel í. (2001). Genel dokular için histolojik inceleme metotları. Histolojik boyama teknikleri, 1. Baskı, s. 51-96. Palme Yayıncılık, Ankara, Türkiye.

23. Martínez L, Cilla I, Beltrán JA, et al. (2006). Effect of Capsicum annuum (Red Sweet and Cayenne) and Piper nigrum (Black and White) pepper powders on the shelf life of fresh pork sausages packaged in modified atmosphere. Journal of Food Sci. 71: 4853.

24. Algan G, Toker C. (2004). Bitki Hücresi ve Bitki Morfolojisi Laboratuvar Kitabı. Ank. Üniv. Fen Fak Yayınları No:139, Ankara Üniversitesi Basım Evi, Ankara, Türkiye. 
25. Gıda, Tarım ve Hayvancılık Bakanlığı, Gıda Hijyeni Yönetmeliği. Resmî Gazete 2011/28145.

26. Değirmencioğlu A, Arslan M, Gökgözoğlu i ve ark. (2006). Klasik tip ve ısıl işlem uygulanarak olgunlaştırılan sucukların özelliklerindeki değişimlerin belirlenmesi üzerine bir araştırma. Türkiye 9. Gıda Kongresi 5: 401-402.

27. Ercoşkun H, Ertaş AH. (2003). Fermente et ürünlerinin lezzet bileşenleri ve oluşumları. Gıda Mühendisliği Dergisi 16: 38-44.

\section{Sorumlu Yazar:}

Fadime TONBAK

Atatürk Üniversitesi, Veteriner Fakültesi, Gıda Hijyeni ve Teknolojisi Anabilim Dalı, Erzurum, TÜRKIYE

E-posta: ftonbak80@gmail.com 